\title{
Glacier disequilibrium in the Convoy Range, Transantarctic Mountains, Antarctica
}

\author{
T. J. ChinN \\ Institute of Geological and Nuclear Sciences Ltd, Crown Research, Dunedin, New Zealand
}

\begin{abstract}
Field work for a geological map of the Convoy Range included mapping glaciers, moraines and surficial deposits. A range of glaciological indicators, including supraglacial and other moraines and margin morphology, has been used to assess the present equilibrium of the glaciers. Fields of rafted supraglacial moraine have accumulated over long periods of time at specific low-gradient, low-velocity locations. As the glacicr regime changes, the shape of the moraine field distorts, signalling a change in flow pattern. By reversing the ice-flow vectors directed at the moraine field, the directions from whence the debris came are shown. Unsorting the contortions of supraglacial moraine fields reveals the nature of the changes in glacier regime. Moraine-field configurations all suggest that local glaciers are expanding in response to higher local precipitation, cstimated to have occurred between 2000 and 8000 year BP, most likely coincident with the world-wide "climatic optimum" of about 6000 year $B P$.

Ice-cliff morphology, fresh terminal moraines and boulder trains indicate that larger local glaciers are currently receding from a Holocene maximum, while the margin of the large Mackay Ice Sheet outlet glacier shows no evidence of recent recession and is probably close to its Holocene maximum. In contrast, areas of present snow cover are expanding, superimposing a recent positive balance (decades to hundreds of years), which has yet to reverse a general recession of mid- to high-altitude glacicrs. Local hollows in some névé areas imply that glacier flow is not in equilibrium with snow accumulation.
\end{abstract}

\section{INTRODUGTION}

Glaciers, moraines and surficial deposits were mapped during field work for a geological map sheet of the Convoy Range (Pocknall and others, 1994). The Convoy Range is a north-south-trending mountain range north of the Dry Valleys region of McMurdo Sound, Antarctica (Fig. 1). The range descends eastward from $2000 \mathrm{~m}$ at the East Antarctic ice sheet to $800 \mathrm{~m}$ at the coastal glaciers. Outlet glaciers of Mawson and Mackay Glaciers bound the area to the north and south. None of the ice from inland sources enters the low eastern areas. The range is arid, with extensive ice-free areas, indicating that ablation exceeds precipitation over most of the area.

This study presents information on the present equilibrium of the glaciers of the area as deduced from the disposition and configuration of drifting supraglacial moraine fields, with additional evidence gained from glacier margins and snow cover.

\section{PREVIOUS WORK}

The glaciers of the Convoy Range have been briefly discussed by earlier workers in the region (Gunn and Warren, 1962; Mirsky and others, 1965; Burgess and others, 1981). Their reports described the glacial features only in very general terms, interpreting the low-gradient ablation fields of blue icc as "remnants of larger and more active glaciers" and "generally slow moving or stagnant". No critical assessment of the equilibrium or activity of these glaciers has prcviously bcen attempted, although glaciological studies have been made nearby in the Dry Valleys area. These include mass-balance studies made in Wright Valley (Bull and Carnein, 1970; Chinn, 1980) and a study of the regimen of the Taylor Glacier trunk (Robinson, 1984). A reconnaissance study of the glaciers of the Terra Nova Bay area to the north (Chinn and others, 1989) demonstrated that the present equilibrium of local glaciers could be assessed from elementary. observations. Studies of the margins of polar glaciers have shown that different configurations can provide much information on climate and equilibrium (Holds-" worth and Bull, 1970; Chinn, 1986; Chinn and Dillon, 1987; Chinn and others, 1989) and, in particular, equilibrium can be assessed from ice-cliff heights (Chinn, 1991). A study of a polythermal debris-covered glacier (Chinn and Dillon, 1987) demonstrated that much of the glacier's regimen could be deduced from the pattern of debris cover.

\section{PRESENT GLAGIERS}

Westerly katabatic winds dictate the sites of local glaciers by controlling the shapes and locations of snow-accumula- 


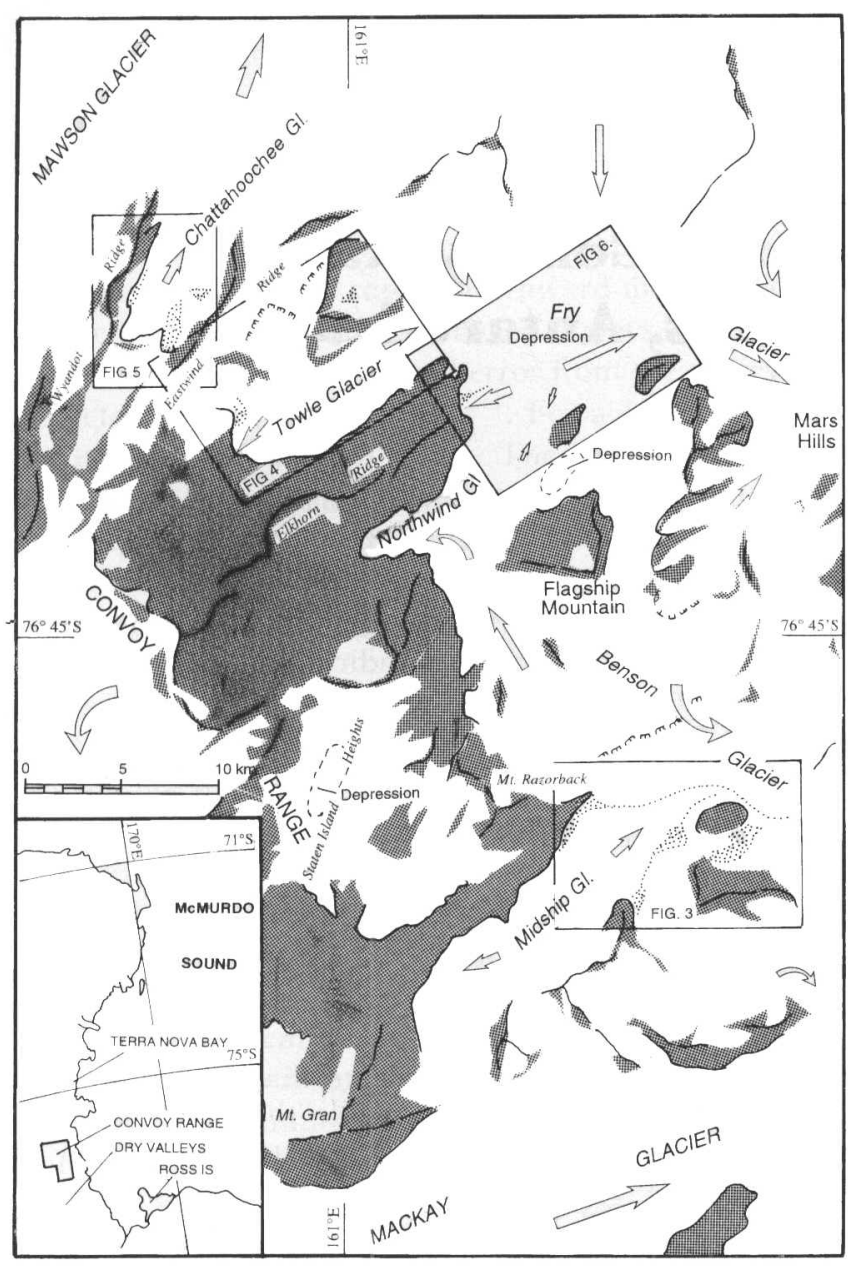

Fig. 1. Location map, showing locations of figures and main ice-flow directions.

tion areas. Snow accumulation increases eastward towards the coast, giving an almost complete ice cover which floods the lower ends of the east-facing valleys. The present glaciers are superimposed on a topography inherited from past glacial and climate systems, and many are discordant with the cirques and valleys (Pocknall and others, 1994). At lower elcvations, icc has flooded into valley systems from the lower ends. Here, ice-flow directions are complex, with diverging and up-valley flows common. There are extensive ablation areas of "blue ice" occurring mainly on Benson and Fry Glaciers.

Glaciers of the region have been subdivided into three types according to ice sources:

(1) The East Antarctic icc sheet to the west and associated outlet glaciers.

(2) A piedmont-glacier complex between the Convoy Range and the coastal hills.

(3) Small local glaciers, mainly at mid to high elevations.

\section{PAST GLAGIAL EXTENTS}

During the Pleistocene, the ebb and flow of glaciers followed major climatic cycles. Cold glacial episodes reduced inland precipitation, causing the East Antarctic ice sheet and local glacicrs to wane while, coincident with world-wide falling sea levels (caused by growth of Northern Hemisphere ice sheets), the marine ice shelves thickened and expanded both inland to invade present coastal areas and outward to near the edge of the continental shelf. These ice-shelf expansions arc known as Ross Sca glaciations (Stuiver and others, 1981; Denton and others, 1989).

During interglacial episodes, inland precipitation probably increased (Stuiver and others, 1981), and both the ice sheet and local glaciers grcw in volume, while the Ross ice shect shrank. In the present climate, which is interglacial, local glaciers and the East Antarctic ice sheet should be close to their maximum extents and levels, and the marine ice shelves should be withdrawn towards minimum positions.

Westward inundation of the lower valleys by inland incursions of the Pleistocene Ross Sea advances carried tills derived from coastal rocks up to altitudes of $1000 \mathrm{~m}$. Granitoid erratics in these tills serve as ice-movement indicators, because the only known sources of granitoid rocks are east of the Convoy Range.

\section{METHODS}

Features indicative of glacier balance and glacier-margin fluctuations include the presence or absence of granitoid erratics which allow differentiation between deposits of the last ice-sheet expansion and those of the Ross Sea events. Here, the distribution of specific granitoid erratics may also permit reconstruction of past icc-flow trajectories.

On local glaciers, estimates were made of the accumulation-area ratio - the ratio of the accumulation area to that of the entire glacier. On average, glaciers in equilibrium have ratios of near 0.6 UNESCO/IAHS. 1970). Recent ice-margin fluctuations were assessed from both recent_moraines and the morphology of cliffed margins following the method of Chinn (1991).

\section{Evidence from supraglacial moraine fields}

Ice flow normally conveys debris completely through a glacier system to be dumped at the terminus. But, on many low-gradient, low-velocity, complex strcams of Antarctic glaciers, local ablation may exceed flow and ice flow is then directed laterally towards these local ablation centres. Over long periods of time, accumulation by ablation and converging flow at low-gradient, lowvelocity polar glacier systems may form extensive fields of supraglacial moraine, the most spectacular example reportcd being the $20 \mathrm{~km}$ long supraglacial moraine between Beardmore and Law Glaciers (Cassidy and others, 1992). These drifting moraine fields have a morphology determined by ice flow and ablation, and are located both at glacier margins and at isolated "blucicc" fields. Those occurring in the middle of ice fields have been the sites of many meteorite finds and have been termed meteorite-stranding surfaces (Cassidy and Whillans, 1990; Cassidy and others, 1992). Where there is no loss of debris, such supraglacial moraines accumulate for as long as the particular glacial regime continues. Boulderweathering and metcorite-exposure ages Cassidy and Whillans, 1990) suggested that many ablation centres may 


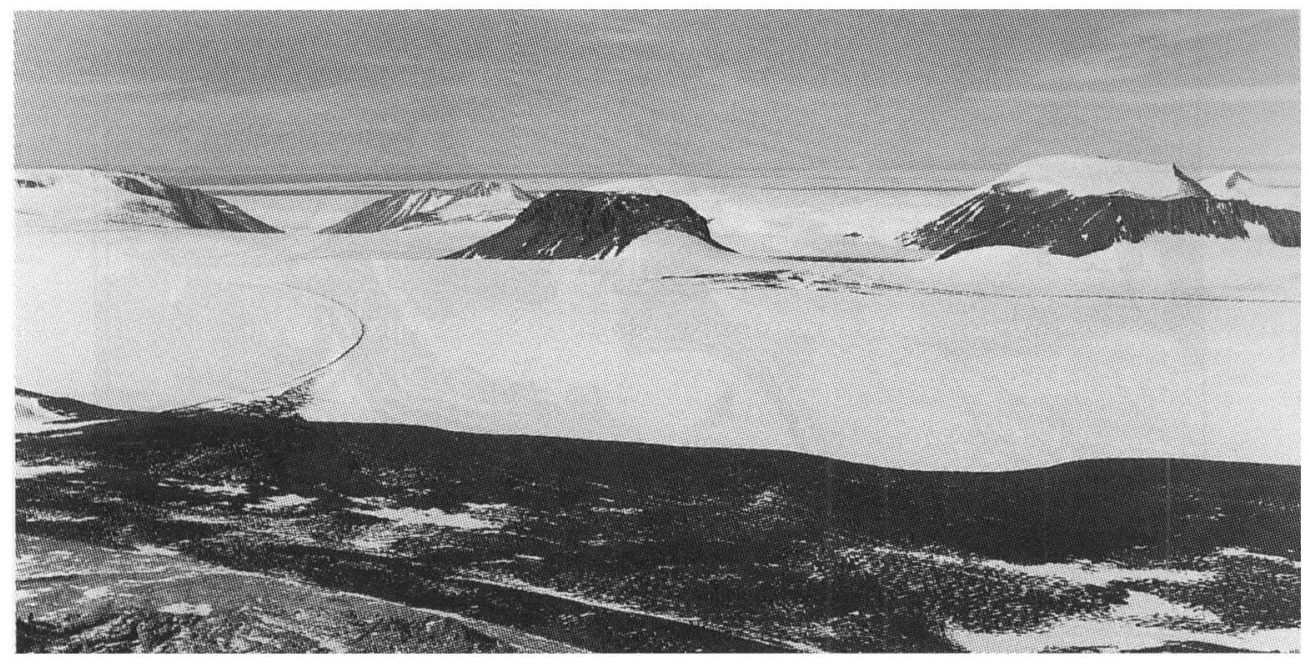

Fig. 2. Jetsam Line ${ }^{*}$ and Flotsam Moraines from Mount Razorback. See text for explanation.

persist for over $0.5 \mathrm{Ma}$. The antiquity and numcrous occurrences of these moraine fields indicate remarkable persistence of stability in Antarctic ice regimes.

When the glacier regime changes sufficiently to deform or to "drain" a moraine field, the patterns within the ficld will be distorted by the changed ice flow, signalling a change in flow regime. The results may appear superficially similar to moraine configurations on surging glaciers but the perturbations to polar moraines can arise from very minor changes to the glacier regime, operating over very long intervals. The shape and distribution of supraglacial debris areas can give much information on glacier equilibrium and movement. By tracing back along ice-flow vectors heading to a moraine field, the directions from whence the debris came can be determined. Ice-flow vectors closely follow surface slope and may be approximated by normals to mapped contours.) By this method, distortion and folding of supraglacial morainc fields werc unravelled to ascertain the nature of changes to the glacier regime.

\section{RESULTS}

\section{Equilibrium of drifting moraine fields}

The presence of large "blue-ice" ablation areas on Fry, Towle, Northwind and Benson piedmont glaciers has led to speculation that these low-gradicnt, low-activity ice masses are wasting remnants of once larger glaciers (Mirsky and others, 1965). However, when the arca of these ice fields is compared with the vast area of their feeder névés, the accumulation- and ablation-area ratios arc found to be compatible with glaciers in equilibrium. A number of moraine fields, however, showed configurations that could not be expected to persist under equilibrium and hence indicate changes currently occurring within the glacier regime.

\section{Jetsam Line* and Flolsam Moraines}

A clear illustration of glacier disequilibrium is given by the Jetsam Line ${ }^{*}$ and Flotsam Moraines complex of the Midship/Benson Glacier complex (Fig. 2). Two sub- parallel lines of debris extend down Benson Glacier from these moraines in a very striking, even curve which continues for $12 \mathrm{~km}$ before terminating where the two lines coalesce on an ablation zone (Fig. 3a). If debris supply to this line had been continuous in the past, the line would continue for the full length of the glacier. The present termination point, "B" (Fig. 3), cannot be stationary as it has to move with ice flow, so its position dates from the time when the two glaciers joined to become confluent.

By back-tracking along present flow lines, it is found that the debris lines originated from a moraine accumulated at the contact between the two glaciers. It is asserted that Jetsam Line moraine originally formed at a terminus of Midship Glacier, separate from the main Benson Glacier icc, at a position somewhere between Mount Razorback and Black Pudding Peak ( $\Lambda$ in Fig. 3 ). Flotsam Moraines were also part of this complex and accumulated in distributory lobes below Mount Brogger. With an expansion of Midship Glacier, the frontal, or Jetsam Line moraine, was carried forward to join the Benson Glacier ice, when both the moraine and a ribbon of Midship Glacier ice were extended around Black Pudding Peak to its present position at B in Figure 3. Meanwhile, an expansion of the snow fields on the slopes of Mount Brogger distorted the Flotsam Moraines as they were carried out into Midship Glacier. The end of Jetsam Line moraines at present must be moving downstream at the rate of ice flow. 'The distance the Jetsam I ine moraine has been carried since the two glaciers joined is about $8 \mathrm{~km}$, and with a flow rate estimated at between 1 and $5 \mathrm{~m} \mathrm{a}^{-1}$ (Robinson, 1984; Chinn, 1986), the time since the glacier expansion commenced is between 8000 and 1600 years.

Hence, this moraine system is interpreted as indicating a significant expansion of Midship Glacier over the last few millennia.

\footnotetext{
"New names indicated by * are subject to Geographic Board approval.
} 


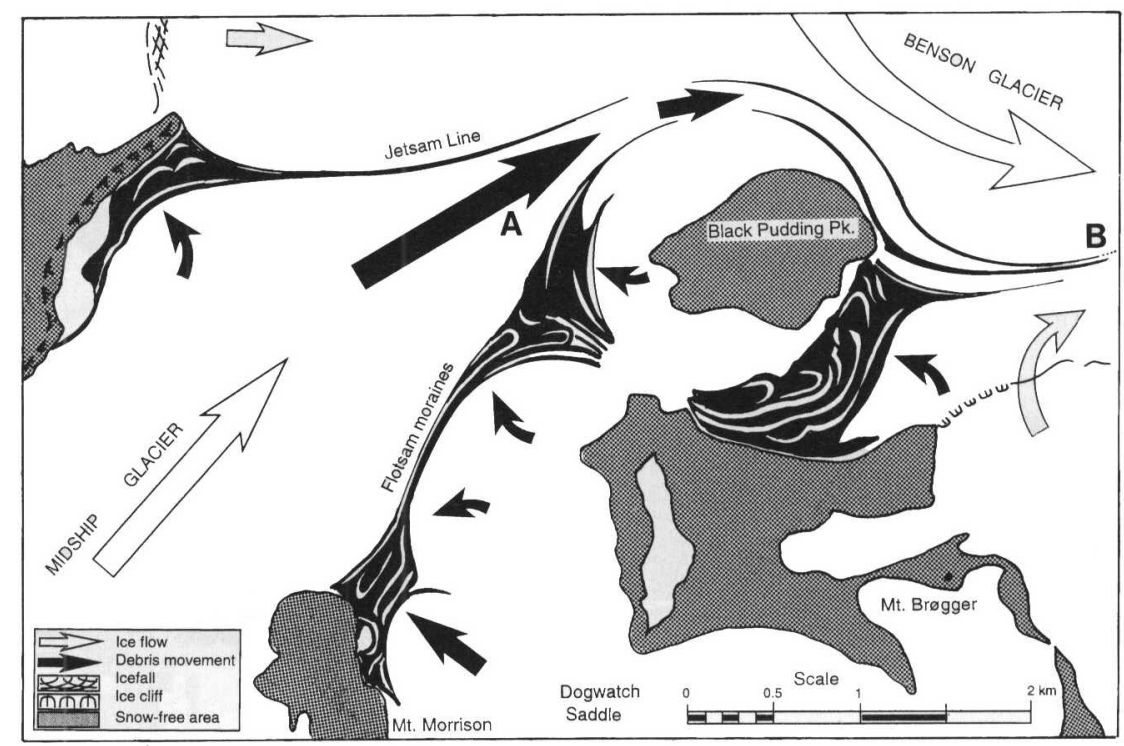

a

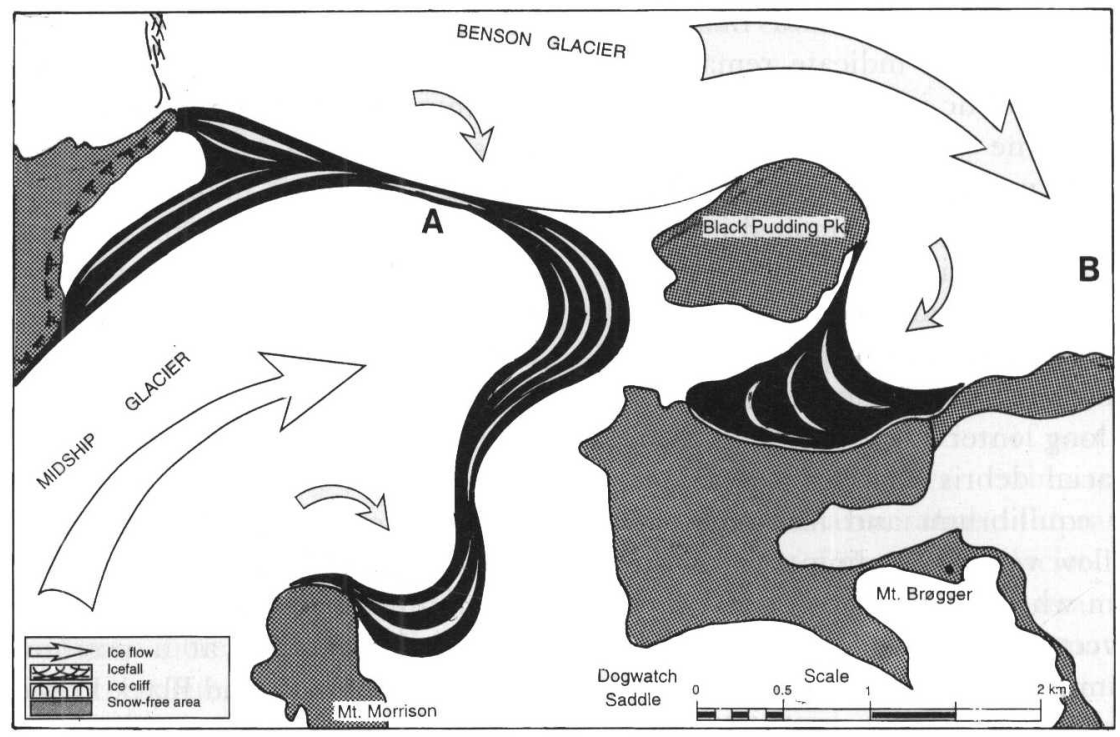

b

Fig. 3. Jelsam Line ${ }^{*}$ and Flotsam Moraines. a. Present configuration. b. Conjectural configuration for accumulation of supraglacial debris. See text for explanation.

\section{Slackwater and Eddy ${ }^{*}$ Cirques}

Arcuate debris bands in Slackwater and Eddy Girques (Fig. 4a) were presumably carried into these cirques by distributory lobes of Towle Glacier at a time when ice flow into these cirques from Eastwind Ridge was limited to non-existent (Fig, 4b). Increased ice input from Eastwind Ridge into the cirques has reversed flow and the moraine fields have distorted as they drifted slowly back out of the cirques towards the main trunk of Towle Glacier. Any debris that may have accumulated in Riptide Cirque has been completely swept away. Being close to the snow line, where net balance at the ice surface is close to zero, these moraines may have been near their present positions for some thousands of years.

The patterns of these moraine fields are interpreted as indicating expansion of the glaciers on the local ranges within the last few millennia.

\section{Chattahoochee Glacier}

Two moraine fields either side of the "névé" of
Chattahoochee Glacier (Fig. 5a) have no obvious source for the debris. Their positions suggest that they are the lateral remnants of a moraine ficld which accumulated when a distributory glacier flowed northwestward into this valley (Fig. 5b). It is suggested that increased snow accumulation blowing over the headwall saddle has reversed the direction of ice flow but has been insufficient to carry all of the debris away.

Moraines of this glacier are interpreted as indicating an expansion of the glaciers on the local ranges within the last few millennia.

\section{Bowesprit Moraine}

A fcature which supports the idea that at least a part of these ice fields is a remnant of an earlier system is Bowsprit Moraine, at $800 \mathrm{~m}$ above sea level between Towle and Northwind Glaciers. It is discordant with the present glacier regime (Fig. 6). The debris is a medial moraine at the glacier front and presumably is of englacial origin. However, the entire area of debris lies 


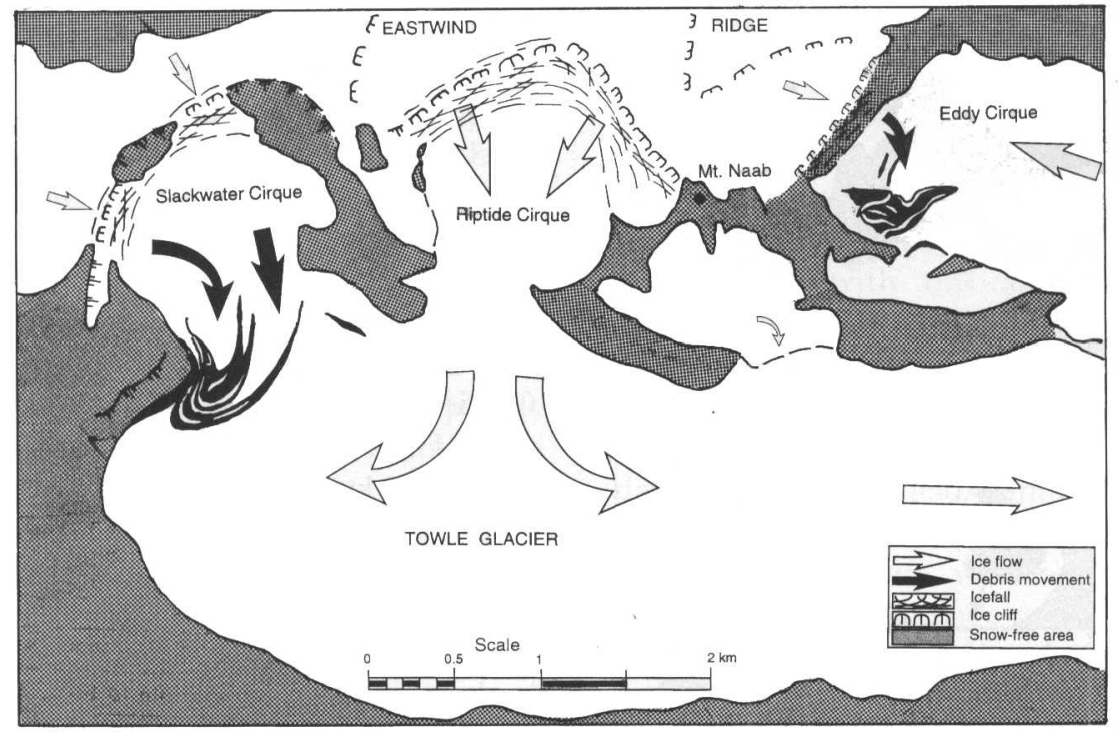

a

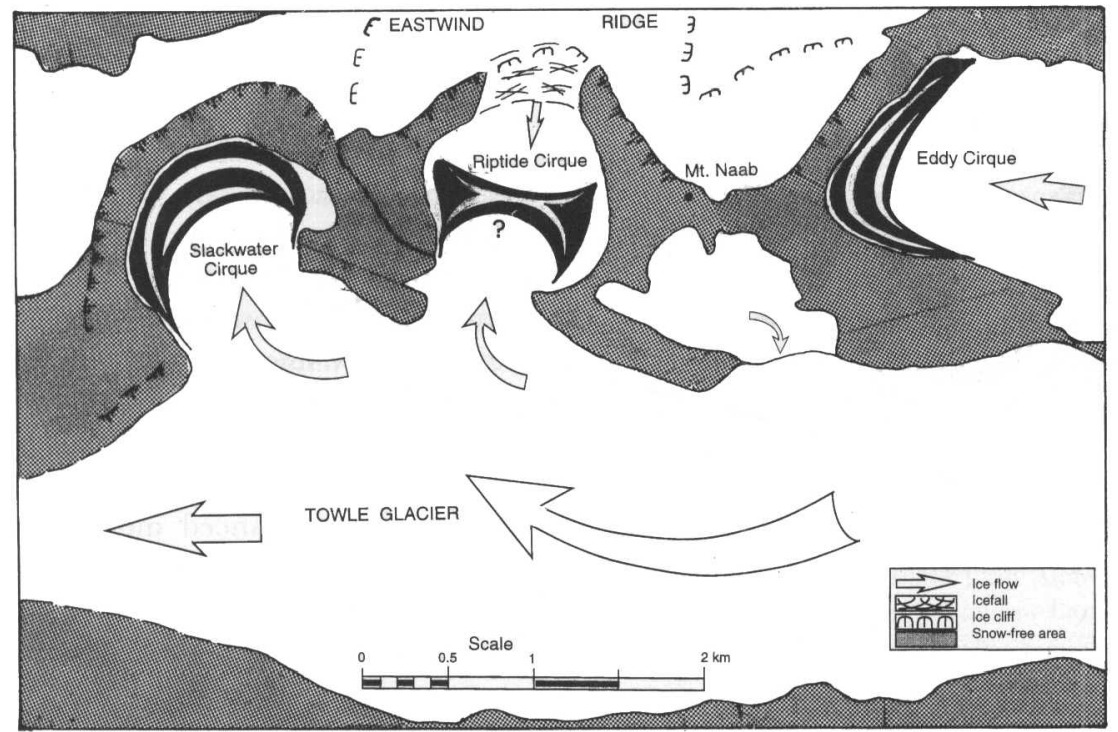

b

Fig. 4. Slackwater and Eddy ${ }^{*}$ Cirques. a. Present configuration. b. Conjectural configuration for accumulation of supraglacial debris. See text for explanation.

in an ablation area flowing from a broad ice divide on Fry G]acier where there is currently no source of supply to the moraine. The debris includes a pink granitc which is known only to the east in the vicinity of Mars Hills, a site which is now "downstream" and at a lower altitude than Bowsprit Moraine. The intervening glacier surfaces are at present so close to being horizontal that present flow directions cannot be accurately assessed, but it is assumed that a reversal of flow has occurred since the last time that ice of Fry Glacier was at an elevation enabling westward flow towards Bowsprit Moraine. This could have occurred only at the last high stand of the last Ross Sea glaciation, dated from the nearby Taylor Valley at between 13000 and 6000 year BP (Denton and others, 1989). Presuming that icc surrounding the moraine can be no younger than this event begs the question of how could ice have survived a pcriod of perhaps 6000-13000 years in this ablation zone? With an estimated annual ablation rate of $200 \mathrm{~mm} \mathrm{a}^{-1}$ (Chinn, 1980) over this period, about $2 \mathrm{~km}$ of ice must have been lost from the glacier surface at the moraine location. 'T'he problem may be partially resolved if this ice loss has, until relatively recently, been compressed and replaced by a westward flow of Fry Glacier ice. Alternatively, or in conjunction with this mechanism, the moraine and associated ice may have resided for most of the period beneath an expanded accumulation zone overlying an area of very limited movement by flow.

Whatever its origin, this fcature is a relict configuration: one of the few known cases of relict ice within a glacier.

\section{EQUILIBRIUM OF ACGUMULATION AREAS}

Present mass balance of the smaller local glaciers was estimated from the accumulation-area ratio. The smaller mid-altitude glaciers of the Convoy Range all have very limited or no ablation areas with bare ice showing, their 

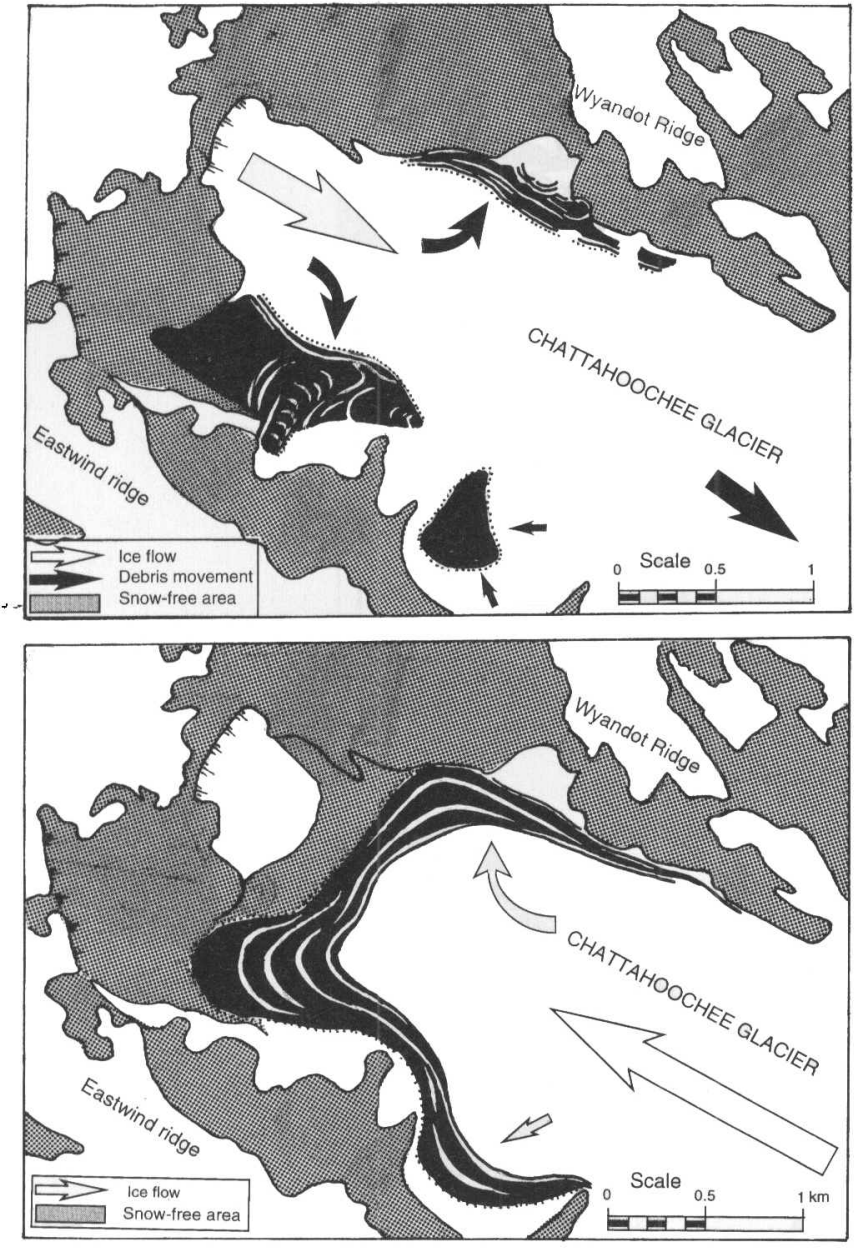

Fig. 5. Challahoochee Glacier. a. Present configuration. b. Conjectural configuration for accumulation of the supraglacial debris. See text for explanation.

lower margins are commonly entirely covered by snowdrifts. Estimated ratios, in the range of $0-0.4$, are well below the equilibrium mean of 0.6 , and are very similar to those of the nearby Terra Nova Bay area Chinn and others, 1989). The disproportionately low area of ablation suggests that the region has recently (in terms of decades? undergone a change of climate to produce more extcnsive snow cover, with snowfields encroaching over both existing glaciers and bare ground. The change is interpreted as indicating an increase in precipitation over the past century.

\section{Névé disequilibrium features}

Glacier accumulation areas seldom give hints of their state of balance but large-scale sags, up to $100 \mathrm{~m}$ in depth and over $1 \mathrm{~km}$ in width, were observed in snowfield areas of Fry Glacier, Staten Island Heights and in a snowfield north of Flagship Mountain (Fig. 1). Given sufficient time, ice flow will ultimately fill such hollows. These features are interpreted as reflecting underlying topography beneath a "thin" growing snow field where ice flow has yet to reach equilibrium with accumulation.

\section{Lake levels}

Trends in level of lakes and ponds within the region also indicate climate trends. Stranded algae around the margins of ponds show that surface levels have been lowering. Although this trend contrasts with rising lake levels of the nearby Dry Valleys area (Chinn, 1993), both results indicate climate warming. This seemingly paradox stems from the position of the lake with respect to the regional snow line. In the Convoy Range, lakes are close to the regional snow line and warming climate has increased precipitation (snowfall) so that meltwater runoff has diminished (Chinn, 1979), while the same warming has enhanced meltwater run-off into the Dry Valleys lakes, which are well below the snow line.

\section{Equilibrium at the glacier margins}

Polar glaciers of the McMurdo Sound region terminate in various forms, ranging from gentle ramps through domed fronts to calving icc cliffs. It has been shown that the equilibrium of a glacier margin may be assessed from its

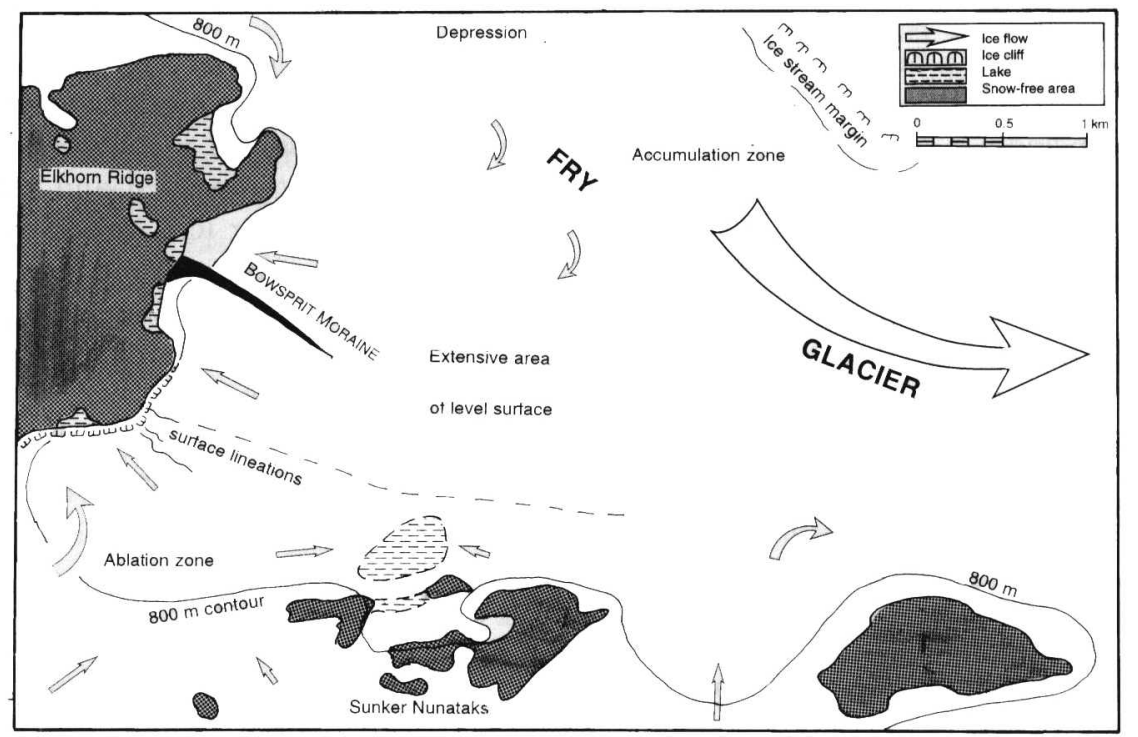

Fig. 6. Bowsprit Moraine, showing present position and ice-movement directions. See text for explanation. 
morphology and, in particular, ice-cliff equilibrium may be assessed from its geometry (Chinn, 1986, 1991). Where there is a well-developed apron and the total cliff height is over $30 \mathrm{~m}$ then the glacier front is advancing (Chinn, 1986, 1991). Few ice cliffs are well developed in the area but those seen were all below $30 \mathrm{~m}$ in height and displayed little to no apron formation. Taken together, these observations indicate that the glaciers are receding.

One glacier on Mount Brogger had low icc cliffs indicative of a receding front but was completely surrounded by a permanent snowfield. The implication is that this glacier is continuing to withdraw in response to a past climate of lower precipitation, while a relatively recent expansion of snow cover has been superimposed upon this glacier recession.

\section{Equilibrium from recent moraines}

Margins of glaciers were examined to see whether the ice was over-riding or withdrawing from recent moraines. Limitcd cxposures of the margin of Mackay Ice Sheet outlet glacier show no evidence of recent recession nor any Holocene moraines. This glacier is likely to be close to its Holocene maximum level.

Margins of smaller local glaciers and piedmont glaciers have Holocene moraines from within a few metres to some hundreds of metres from their margins. These moraine positions indicate general recession but, as these glaciers have response times to climate changes of the order of thousands of years (Chinn, 1986), this trend is an artifact of a period of recession prior to the present positive balance.

\section{GONGLUSION}

Moraine fields in the Convoy Range indicate glacier disequilibrium. Moraine configurations all suggest that local glaciers are expanding in response to a past "warmer" climate of higher local precipitation, estimated from the amount of moraine movement on Benson Glacier to have occurred between 2000 and 8000 year BP. 'This "warmer" period is most likcly coincident with the worldwide "climatic optimum" at about 6000 year BP. The moraine fields all occur on large glaciers which have long response times, so that the expansion which they record has presumably already passed through the smaller steeper glaciers, leaving them in a state of retreat.

Small moraines in front of some local glaciers indicate that these glaciers have been slightly larger at some past time during the Holocene and are currently retreating. However, ice-sheet variations recorded by moraines at the margin of Mackay Glacier show no cvidence of Holocene recession, suggesting that this glacier is close to its Holocene maximum level.

Expanding areas of snow cover have given a Recent (decades to hundreds of years) positive balance to the mid- to high-altitude glaciers. This change to positive mass balance, which has yet to affect the fronts of any of the glaciers, has been superimposed on a general state of glacial recession. In this area of continuous sub-zero temperatures, climate warming is indicated by an increase in prccipitation and subsequent glacier ad- vance, possibly since the "Little Ice Age" which ended in the last century.

When all features indicating glacier equilibrium are compared, there are two apparently conflicting results; whereas one set of indicators suggests that glaciers are advancing, another set points towards recession. There is no problem with this apparent conflict when one considers the differing response times of polar glaciers. The time taken for a change in mass balance from a climate change to pass through to the glacier front is in the order of thousands of years (Chinn, 1986). The drifting moraine fields and margin fluctuations are responding to glacier thickening from long (thousands of years) in the past, whereas the surface mass-balance changes indicate a change to positive mass balance in the immediate past (tens to hundreds of years).

\section{ACKNOWLEDGEMENTS}

The expedition is grateful for the co-operative support provided by the personncl of Scott Basc and logistics support provided by the U.S. Navy. This research was carried out under contract No. CO5232 of the New Zealand Foundation for Research and Technology.

\section{REFERENGES}

Bull, C. and C. R. Carnein. 1970. The mass balance of a cold glacier: Meserve Glacier, south Victoria Land, Antarctica. International Association of Scienific Hydrology Publication 86 (Symposium at Hanover 1968 - International Sympasium on Antarctic Glaciologial Exploration , $429-446$.

Burgess, C.J., A. Palmer and J. M. Anderson. 1981. The geology of the Fry Glacicr area, south Victoria Land, Antarctica, with particular reference to the Taylor Group. V.Z. 7. Geal. Geophys, 24 3), 373-388.

Cassidy, W.A. and I. M. Whillans, eds. 1990. Workshop on Antarctic Metorite Stranding Surfares held at Vmizersity of Pittshurgh, 7uly 13-15, 1988. Houston, TX, Lunar and Planetary Institute. LPJ Technical Report 90 03.)

Cassidy, W.A., R. Harvey, J. Schutt, G. Delisle and K. Yanai. 1992. The meteorite collection sites of Antarctica. Meteorilics, 27 35 ; 490-525.

Chinn, T.J.H. 1979. Impact of "extreme" events on the Dry Valleys area. A.Z. Antart. Rec, 2(2),9-13.

Chimn, I.J.H. 1980. Glacicr balances in the Dry Valleys area, Victoria Land, Antarclica. Intemational Association of Hydrological Sciences Publication 126 Workshop at Riederalp 1978 World Glacier Inventory), 237-247.

Chinn, T.J.H. 1986. Structure and equilibrium of the Dry Valleys glaciers. N.Z. Antart. Rec., 6 (Special Supplement), 73-88.

Chinn, T.J. 1991. Polar glacier margin and debris features. Mem. Sor. Geol. Hal. 46, 25-44.

Chinn, T.J. 1993. Physical hydrology of the dry valley lakes. Antart. Res. Ser., 59, l j 51 .

Chinn. T.J.H. and A. Dillon. 1987. Observations on a debris-covered polar glacier "Whisky Glacier", James Ross Island, Antarctic Peninsula, Antarctica. f. Glaciol., 33(115), 300-310.

Chinn. T.J.H., I. E. Whitehouse and H-C. Hofle. 1989. Report on a reconnaissance of the glaciers of Terra Nova Bay arca. Geol. Jahth. Reilhe E 38, 299-319.

Denton, G. H., J. G. Bockheim, S. C. Wilson and M. Stuiver. 1989. Late Wisconsin and Early Holocene glacial history, inner Ross Embayment, Antarctica. Quat, Res, 31(2), 151-182.

Gunn, B.M. and G. Warren. 1962. Geology of Victoria Land between the Mawson and Mulock glacicrs, Antarctica. N.Z. Geot. Surz. Bull. 71. Wellington, Department of Scientilic and Industrial Research.

Holdsworth, G. and C. Bull. 1970. The flow law of cold ice: investigations on Meserve Glacier, Antarctica. International Association of Scientific Hydrology Publication 86 Symposium at Hanover 1968 -.. International Symposium on Antartic Glaciological Explorationj, 204-216. 
Mirsky, A., S.B. Treves and P.E. Calkin. 1965. Stratigraphy and petrography, Mount Gran area, southern Victoria Land. Antarctica. Antart. Res. Ser., 6, 145-175.

Pocknall, D. T., T.J.H. Ghinn, R. Sykes and D. N. B. Skinner. 1994 Geology of the Convoy Range area, southern Victoria Land, Antarcica. Institute of Geological and Nuclear Sciences Geological Map 11. Lower Hutt (New Zealand), Institute of Geological and Nuclear Sciences Ltd.

Robinson, P. H. 1984. Icc dynamics and thermal regime of 'Taylor Glacier, south Victoria Land, Antarctica. F. Glaciol. 30(105), 153-160.

Stuiver, M., G.H. Denton, T.J. Hughes and J. L. Fastook. 1981.
History of the marine ice sheet in West Antarctica during the last glaciations: a working hypothesis. In Denton, G.H. and T. H. Hughcs, eds. The last great ice sheets. New York, etc., John Wiley and Sons, 319-436.

CNESCO/IAHS, 1970. Perennial jce and snow masses. CVESCO Technical Papers in IIydrology 1.

The accuracy of references in the text and in this list is the responsibility of the author, to whom queries should be addressed. 